\title{
A Historical Sociology Perspective on the Legacy of State Formation and Dynamics of Arab Revolts in Libya: From Elusive Authority of Qadhafi to Masses Craving for Democracy
}

\author{
Ali Bilgenoğlu* \& Hikmet Mengüaslan**
}

\begin{abstract}
This study aims to question the appropriateness of the "transition to democracy" paradigm in the Arab Revolts context with a specific focus on Libya. Arguing that the real problem lies at the meta-theoretical level, the assumptions and the empirical incongruities of democratization and post-democratization perspectives will be elaborated. With historical and social-minded analysis, the political developments in Libya will be approached with a historical sociology perspective complemented by the political economy of regime security. The interaction within the state-society complex in the framework of a complex relationship with regional/international level dynamics will be given a specific focus and unlike deterministic-teleological and reductionist democratization/post-democratization perspectives, the following question will be tackled: What happened politically in Libya in the course of the Arab Revolts?
\end{abstract}

Keywords: Historical Sociology, Democratization/post-democratization, Authoritarianism, Arab Revolts, Libya

Assistant Professor, Adnan Menderes University, TR, Department of International Relations, orcid.org/0000-0002-9097-1737, ali.bilgenoglu@adu.edu.tr

** Research Assistant, Middle East Technical University, TR, Department of International Relations, orcid.org/0000-0003-4836-5108, hikmetm@metu.edu.tr 


\section{Libya'da Arap İsyanlarnın Dinamikleri ve Devlet Oluşumu Mirasına Tarihsel Sosyolojik Bir Bakış: Kaddafi'nin Güvenilmez Otoritesinden Demokrasi Arayan Kitlelere}

Ali Bilgenoğlu* \& Hikmet Mengüaslan**

Öz

Bu çalışma Arap İsyanları bağlamında Libya’ya odaklanarak "demokrasiye geçiş” paradigmasının uygunluğunu sorgulamayı amaçlamaktadır. Asıl problemin metateorik düzeyde yer aldığı tartışılarak, demokratikleşme ve demokratikleşme sonrası yaklaşımlarının varsayımları ve ampirik uyuşmazlıkları incelenecektir. Tarihsel ve sosyal odaklı bir analiz ile Libya'daki siyasi gelişmeler rejim güvenliğinin politik ekonomisi ile desteklenen tarihsel sosyolojik bir yaklaşımla ele alınacaktır. Bölgesel/uluslararası dinamiklerin karmaşık ilişkisi çerçevesinde devlet-toplum bileşiğinin etkileşimine özellikle odaklanılacak ve deterministik-teleolojik ve indirgemeci demokratikleşme/demokratikleşme sonrası yaklaşımlarının aksine, “Arap İsyanlarına giden süreçte Libya'da siyasi açıdan neler oldu” sorusunun cevabı araştırılacaktır.

Anahtar Kelimeler: Tarihsel Sosyoloji, Demokratikleşme/Demokratikleşme Sonrası, Otoriterlik, Arap İsyanları, Libya

Dr. Öğr. Üyesi, Adnan Menderes Üniversitesi, TR, Uluslararası İlişkiler, orcid. org/0000-0002-9097-1737, ali.bilgenoglu@adu.edu.tr

** Araştrma Görevlisi, Orta Doğu Teknik Üniversitesi, TR, Uluslararası İlişkiler, orcid. org/0000-0003-4836-5108, hikmetm@metu.edu.tr 


\section{Introduction}

The conceptualizations "democratization" and "transition to democracy" have been among highly debated concepts in International Relations (IR) theory and Middle Eastern Studies (MES). It has attracted considerable interest from academic and political circles. It is not surprising that the MENA (Middle East and North African) region hosted various types of regimes from authoritarian monarchies to socialist republics. The implications of such an interest manifest itself in the foci and methods of the analysis of democracy, although "democracy" is not on the eye of the beholder. ${ }^{1}$ In this respect, this study, aims to scrutinize the existing conceptions of democracy and conceptualization of "transition to democracy." The focus of the study, which elaborates on the deficiencies of existing conceptualizations, consists in the reappraisal of Libyan revolts on the course of the Arab Revolts through the perspective of historical sociology and political economy of regime security.

There are various arguments in the literature on democracy/democratization. It has taken its modern concept shape according to experiences of Western societies, and might also sound like a cultural instrument, which is inappropriate for MENA societies due to the prevalence of Islamic culture and particular socio-cultures. The problem, however, lies with the tendency of identifying certain pre-conditions for democracy rather than with cultural differences. The relationship between democratic rule and economic development, the existence of civil society, and liberalization ${ }^{2}$ is complex. Yet, it is assumed that there will be a linear transition to democracy when one or two conditions are provided. The existing analyses either focus on structural causes or solely look for the internal dynamics for the explanation. Empirical examples disprove such an assumption, as political movements -liberalization/democratization- can be found from time to time in the region. There are arguments against conceiving of Islam

Rex Brynen, Bahgat Korany and Paul Noble, "Introduction: Theoretical Perspectives on Arab Liberalization and Democratization," in Political Liberalization and Democratization in the Arab World. Vol.1: Theoretical Perspectives, ed. Rex Brynen, Bahgat Korany and Paul Noble (Boulder, CO: Lynne Rienner, 1995), 3.

2 Thomas Carothers, "The End of the Transition Paradigm," Journal of Democracy 13, no.1 (2002). 
as misappropriate to democracy and liberalization. ${ }^{3}$ Esposito and Piscatori point to the consultation (shura) in the Islamic way of governing, which to some extent resembles participation and consultation in democracy. ${ }^{4}$

The same applies to the framework of "transition to democracy." It conceives of any departure from autocratic, monarchical rule as a move towards democratization. Nevertheless, one must keep in mind that authoritarian structures have demonstrated high resilience in the region, which becomes a serious challenge to "transition to democracy." In this respect, the study discusses that such teleological-determinist and reductionist approaches result in misleading analyses considering the region where various social forces dynamically interact in both domestic and regional/global levels. ${ }^{5}$

In order to overcome deficient methods of analysis and conceptualizations, the study asserts that the historical sociology perspective can contribute to build a holistic framework. Such a framework which is sensitized to the interaction of social forces at domestic and regional/international level provides a more explanatory approach.

The political process in Libya becomes significant to inquire the applicability of pre-determined frameworks. Furthermore, the analysis of uprisings turning into civil war is a severe test to observe the implications of interaction between dynamics at the domestic and regional/international level. The framework elaborates on what was politically happening in the Libyan case within the context of the Arab Revolts. For this purpose, the study prioritizes the political economy of regime security and inquires the interaction between both intra- and inter-state actors during the revolts. It examines the processes of state-building and the political-economic basis of institutionalization. While reviewing the implications of "transition to democracy" for IR theory and MES, the study examines through a historical sociology perspective, what happened politically in the Libyan case on the course of the Arab Revolts.

Alfred Stepan and Juan J. Linz, "Democratization Theory and the "Arab Spring,", Journal of Democracy 24, no.2 (2013): 17.

4 Juan L. Esposito and James P. Piscatori, "Democratization and Islam," Middle East Journal 45, no. 3 (1991):434.

5 Raymond Hinnebusch, "Historical Sociology and the Arab Uprising," Mediterranean Politics 19, no. 1 (2014a). 
The following section categorizes the approaches to democratization and post-democratization while inquiring their basic notions. Against these arguments, in the third section, the possible contributions of the historical sociology perspective are discussed. The fourth section examines political processes in Libya and the dynamics of uprisings through the historical sociology perspective.

\section{Analyzing the Democratization/Post-democratization Approaches}

The scrutiny of the "transition to democracy" framework entails inquiry of the basic notions in democratization and post-democratization perspectives. As evident from their names, democratization and post-democratization perspectives examine the political processes especially in "developing" and "third-world" societies. The nature of political regimes in these societies has become an object of study through the waves of democratization, and both perspectives develop their frameworks to inquire the causal factors relevant to democracy.

The democratization literature primarily concentrates on the conditions conducive/preventive to democracy. To comprehend the democratization process and to search for the obstacles, constraints, failures of human agency, Burnell discusses that it is necessary to look for the causes that facilitate democracy. ${ }^{6}$ It is an epitome of the preconditions approach; that is, the relation between the increase in income per capita and the enthusiasm for democracy it creates. An interesting statistical fact is that there is a strong tendency for democracy to be associated with national wealth, and democratization to be associated with economic liberalization; however, it has two main limitations: it says nothing about causation, and it says nothing about exceptional cases. ${ }^{7}$ Another tendency is the ranking according to the level of democracy, which is calculated through certain conditions. Schlumberger, in this respect, questions the validity of the

Peter Burnell, "Arrivals and departures: A preliminary classification of democratic failures and their explanation," Commonwealth \& Comparative Politics 36, no. 3 (1998): 9.

7 Ian McLean, "Democratization and economic liberalization: Which is the chicken and which is the egg?" Democratization 1, no. 1 (1994): 38. 
Freedom House Index. He points out that the arbitrariness of the variables included in the calculation as they are decontextualized from their social, institutional, and cultural settings. However, it does not take into account the process and distinguish qualitatively between democratic and nondemocratic regimes. ${ }^{8}$

Contrary to the democratization perspective, the post-democratization approach denotes going beyond the conditions for democracy. However, it seems to turn into a version of the transition in reverse. ${ }^{9}$ Instead of transition towards democratization, the analytical focus here is the resilience of authoritarianism in these societies. It is the question of how regimes could stay in power. Such a focus renders essential the political instruments such as repression, co-optation, and economic instruments such as patrimonial relations between regime and selected groups. Bellin underlines some factors that lead to the resilience of authoritarian regimes, such as rentier economy, international support network, low level of institutionalization of coercive apparatus, low level of popular mobilization. ${ }^{10}$ According to Ehteshami, ideology, patrimonial relations, and repressive power are the factors that mostly brought forward in analyses concentrated on the robustness of authoritarianism in the MENA region. ${ }^{11}$ Valbjorn argues that the significant part of the post-democratization paradigm applies a regime focused analysis and does not pay attention to societal dynamics. ${ }^{12}$ The post-democratization perspective, therefore, seems to fail to overcome the reductionist tendencies in the democratization literature.

Once the political processes unfold contrary to expectations, and the paradigms fell short of satisfying the analytical purposes, criticisms turn to meta-theoretical foundations. Assessing the obstacles of democratization,

Oliver Schlumberger, "The Arab Middle East and the question of democratization: Some critical remarks," Democratization 7, no. 4 (2000): 124.

$9 \quad$ Morten Valbjorn, "Three Ways of Revisiting the (post-)Democratization Debate After the Arab Uprisings," Mediterranean Politics 19, no. 1 (2014): 157.

10 Eva Bellin, "Reconsidering the Robustness of Authoritarianism in the Middle East: Lessons from the Arab Spring," Comparative Politics 44, no. 2 (2012): 128-129.

11 Anoushiravan Ehteshami et al., "Authoritarian Resilience and International Linkages in Iran and Syria," in Middle East Authoritarianisms: Governance, Contestation and Regime Resilience in Syria and Iran, ed. Steven Heydemann and Reinoud Leenders (Stanford, California: Stanford University Press, 2012), 222-223.

12 Valbjorn, “Three Ways of Revisiting the (post-)Democratization Debate," 158. 
Cavatorta categorizes the perspective as structure-led and agency-led. For Cavatorta, while structure-led explanations generally focus on international factors, rentierism, and Islamic political culture, agency-led explanations underline the role of the ruling elite and Islamist movements. ${ }^{13}$ Such categorization demonstrates that abstraction of structural and agential dynamics from each other limits the explanatory capacities of the analysis while undertheorizing the interaction between structure and agent. On the same account, Valbjorn and Bank point out the meta-theoretical problems in democratization and post-democratization perspectives. For them, the problems in these perspectives are two-fold: first, they are blind to the actual continuity in the apparent changes and second to the actual changes in the apparent continuity. ${ }^{14}$

The Euro-centric nature of the conceptualization also attracts criticism; however, the cultural relativism cannot be an answer. As Sadiki discusses, the limits drawn by the Orientalism-Occidentalism debate could not provide progressive paths for explanatory frameworks. The missing of a robust dialogue within debate in question culminates in the consolidation of ethnocentric perspectives. Instead, Sadiki proposes that there should be a fluid paradigm that enables incorporating the historical and social peculiarities of the Middle East in order to escape from the imposition of the singularity of truth. ${ }^{15}$

In such a context, the arguments of Thomas Carothers in his valuable article entitled "The End of Transition Paradigm" become quite significant for the reappraisal of these perspectives. He identifies five core assumptions that demonstrate the inherent problems leading to incongruence with empirical examples. First, considering any movement from authoritarianism as a move to democracy is not acceptable. Second, proposing a set of sequences for the democratization process is virtually unnecessary and deterministic. Third, the influence of elections is overemphasized. Fourth is ignoring the effects of structural and peculiar factors upon the process, and the

13 Francesco Cavatorta, "The Middle East and North Africa," In Routledge Handbook of Democratization, ed. Jeffrey Haynes (New York: Routledge, 2011): 83-86.

14 Morten Valbjorn and Andre Bank, "Examining the 'Post' in Post- Democratization: The Future of Middle Eastern Political Rule through Lenses of the Past," Middle East Critique 19, no. 3 (2010): 187-188.

15 Larbi Sadiki, "Libya's Arab Spring: The Long Road from Revolution to Democracy," International Studies 49, no. 3\&4 (2012): 287-288. 
last is not paying the necessary attention to the fact that not all states are functioning effectively. ${ }^{16}$ The critical review of basic notions in these perspectives indicates that attempts to revise the conceptions of democracy, authoritarianism, and transitory processes would not contribute as much as expected. In this context, the study elaborates on building a historical sociology framework that can help overcome these meta-theoretical deficiencies in the following section.

\section{Possible Contributions of the Historical Sociology Perspective}

Social reality is an open system, which entails an interactive approach for conceptualizing causal relations between events. "Transition to democracy" as a pre-determined framework culminates in empirical misfits. It is related to the ideological nature of scientific analysis. Once epistemological and methodological notions are inquired, imposing a pre-determined framework indicates the empirical incongruence and misleading conclusions for the complexity of social reality.

The study argues for considering Arab Uprisings as a watershed which has caused shifts in state-society complexes in MENA. These shifts, through a non-deterministic approach, should be considered a call for change. ${ }^{17}$ It will provide a broader perspective to understand the role played by different factors in political-economic structures. The acknowledgment of complexity, however, does not mean that political processes cannot be analyzed scientifically. It points out a method for conceiving causal relations while prioritizing historical-social articulation of state-institutions, the political-economic basis of society, and the interaction between domestic, regional/international structures. The main question becomes what is happening politically? ${ }^{18}$

What is identifying the conjunction of events is crucial to causal relations - the Humean notion of causality. It attributes causality to the events in conjunction. Bhaskar underlines the inadequacy of such a position in

16 Carothers, "The End of the Transition Paradigm."

17 Morten Valbjorn, "Upgrading Post-democratization Studies: Examining a Repoliticized Arab World in a Transition to Somewhere," Middle East Critique 21, no. 1 (2012): 31.

18 Carothers, "The End of the Transition Paradigm," 18. 
attributing causality. Furthermore, such causality leads to a direct shift from explanation to prediction, which cannot be the case when actual social events happen in open systems under the influence of various social forces, dynamics, and mechanisms. ${ }^{19}$ It is related to the understanding of theory. The pre-determined frameworks assume, with a positivist scientific understanding, a reality that can be separated from its context, waiting outside to be discovered as if there is a linear relationship between cause and effect emanating from the conjunction of events. As such a conception is argued to be misleading; it underestimates the complexity of the multiply determined nature of social reality. ${ }^{20}$ Therefore, a theory of social events should acknowledge the historical and social. Historical refers to acknowledging the influence of inherited structures and forces, while social refers to the interaction between structural and agential dynamics. ${ }^{21}$ At the same time, it should acknowledge the complex nature of causality and the diversity of social forces. It can be argued that looking at the failure of the approaches mentioned above as lacking congruity with the empirical domain; the Arab Revolts can be argued to contribute both to democratization and resilience of authoritarianism paradigms. ${ }^{22}$ However, since both perspectives are fixated on a simplistic authoritarian-democratic dichotomy, which resulted in the omission of the complex nature of political regimes and the struggle among social forces shaping them, it is not surprising. To comprehend the complexity of reality and interaction of various dynamics, Tilly underlines the process (democratization/dedemocratization) as an analytical focus which does not have a teleological ending point and incorporates the interaction, the contingency of events and results, the struggle between forces and their capacity of adjustment in the process. ${ }^{23}$

19 Roy Bhaskar, A Realist Theory of Science (New York: Routledge, 2008), 55-56.

20 Milja Kurki and Colin Wight, "International Relations and Social Science," in International Relations Theories: Discipline and Diversity, ed. Tim Dunne, Milja Kurki and Steve Smith (Oxford: Oxford University Press, 2013): 20-23.

21 Kurki and Wight, "International Relations and Social Science," 25.

22 Raymond Hinnebusch, "Towards a Historical Sociology of the Arab Uprising: Beyond Democratization and Post-Democratization," in Routledge Handbook of the Arab Spring Rethinking Democratization, ed. Larbi Sadiki (New York, Routledge, 2014b), 39-40; Valbjorn, "Three Ways of Revisiting the (post-)Democratization Debate," 158-159.

23 Charles Tilly, Democracy (New York: Cambridge University Press, 2007), 22-24. 
The understanding of theory is also relevant to the agent-structure problem in social sciences. Wight underlines the importance of structural and historical explanations. ${ }^{24}$ Since all explanations, either structural or agential, have the unthematized features of structural or agential explanations, they alone are not enough to comprehend the complex nature of reality and multi-level causality. Nevertheless, as Anderson asserts that the American perspective in the Middle East is ahistorical ${ }^{25}$ the first step should be the incorporation of the process of the structures, in other words, highlighting the structural implications.

To Hobson, it is illuminating to present as inherited from past is; therefore, an approach should not take the present as natural, immutable, and reified. ${ }^{26}$ After the modernization theory and the experiences of developed countries do not provide expected outcomes, the focus shifted to the historical analysis of developing societies, while the obstacles of democratization were argued to be located in the transition to modernity and problems related to nation-building. ${ }^{27}$

Hinnebusch discusses that historical sociology posits the co-constitution of inter/transnational and the state levels. ${ }^{28} \mathrm{He}$ highlights the influence of war-making over the state (derived from the European example of state-building), which should be complemented with a political economy perspective. The MENA region, concerning super-power penetration, offers the implications of geopolitical structures. Second, historical sociology enables us to eschew teleological assumptions such as democracy as the endpoint, which is a result of the struggle of social forces and dynamics. The political processes do not unfold linearly.

Third, from a historical sociology perspective, there is no dichotomy of democracy-authoritarianism, rather an expectation of variegated regimes

24 Colin Wight, Agents, Structures and International Relations: Politics as Ontology (Cambridge: Cambridge University Press, 2006).

25 Lisa Anderson, "Searching Where the Light Shines: Studying Democratization in the Middle East," Annual Review of Political Science 9, (2006): 192.

26 John M. Hobson, "What's at stake in 'bringing historical sociology back into international relations'? Transcending 'chronofetishism' and 'tempocentrism' in international relations” in Historical Sociology of International Relations, ed. Stephen. Hobden and John M. Hobson (New York: Cambridge University Press, 2002), 5-9.

27 Raymond Hinnebusch, "Authoritarian Persistence, Democratization Theory, and the Middle East: An Overview and Critique," Democratization 13, (2006): 377.

28 Hinnebusch, "Historical Sociology," 137-138. 
along two poles. It results misleadingly in considering any movement from authoritarianism to democracy as a model. While these two concepts are closely related to each other, since they define different outlooks, they should be identified clearly. Political democratization refers basically to the participation and representation, while political liberalization is related to the expansion of public space through the recognition and protection of political and civil rights. ${ }^{29}$ Such a position might provide a broader perspective, and Saouli points to the influence of state formation over the emergence of contentious politics. His approach is significant in the sense that democracy is only one of the possibilities that can emerge out of the interaction of various dynamics in society. ${ }^{30}$ Fourth, there is no theoretical imposition in historical sociology, rather the historical-structural articulation of the historical-social agent. In this context, as Schlumberger underlines the weaknesses of transition the democracy paradigm, to look for laws of democratization could not capture complex political processes. ${ }^{31}$

By comprehending political developments in the region, the historical sociology perspective looks at state formation and building processes. The state formation-building processes, rather than cultural and regional factors, provide essential insights into the historical-structural articulation of political processes. ${ }^{32}$

Anderson asserts that the emergence of state institutions differs from the European example. They show varying autonomy within state-society complexes. The underlying reasons are two-fold; firstly, the boundaries of the states are incongruent with actual boundaries. Secondly, the state formation process did not benefit all social groups equally, and the influence of domestic political and economic competition has been as effective as the international developments upon the state formation process. ${ }^{33}$ The point

29 Brynen, Korany and Noble, "Introduction: Theoretical Perspectives," 3-4.

30 Adham Saouli, "Back to the future: the Arab uprisings and state (re)formation in the Arab world," Democratization Vol. 22, no.2 (2015): 316.

31 Oliver Schlumberger, "Dancing with Wolves: Dilemmas of Democracy Promotion in Authoritarian Contexts" in Democratization and Development, ed. Dietrich Jung (New York: Palgrave Macmillian, 2006), 43.

32 Lisa Anderson, "Absolutism and the Resilience of Monarchy in the Middle East," Political Science Quarterly 106, no.1 (1991): 2-3.

33 Lisa Anderson, "The State in the Middle East and North Africa," Comparative Politics 20, no.1 (1987): 6 
is to acknowledge the linkage between international and domestic. ${ }^{34}$ Statesociety complexes are both constituted by and constitute the international/ global structures. ${ }^{35}$ States operate in enabling and constraining domestic and international environments. ${ }^{36}$ At this point, the interaction between social dynamics, actors, and the economic, political, and social structure come to the front. To the influence of international over the outcomes, Schlumberger argues that Western policies toward the region do not favor democracy. Instead they lead to the consolidation of authoritarian regimes' repressive actions. ${ }^{37}$ Ritter also points to the nature of values like being Western and its manipulation by the regimes as a discursive instrument, which makes it even harder to demand democracy. ${ }^{38}$ The nature of interaction at the regional level should not be underestimated as it was a factor that played a role on the course of events during the uprisings.

Since the state formation processes in the region mostly resulted in the difficulty to ensure the legitimacy of authority via consensus and participation, ${ }^{39}$ regimes had to apply for repression and co-optation of opposition and the selective alliance of ethnic, tribal and familial identities. It proves the necessity of looking at the state formation process, which is a process of contestation between different groups that are included and excluded. Nevertheless, contentious politics are necessary but not a sufficient condition for political change..$^{40}$ Democratization and postdemocratization approaches are criticized for being thin. They overlook the deep political economy infrastructure and the social forces that give substance to and drive changes in political institutions. ${ }^{41}$ When considering

34 Hobson, "What's at stake in 'bringing historical sociology back into international relations'? Transcending 'chronofetishism' and 'tempocentrism' in international relations," 16-17.

35 Ibid., 21.

36 John M. Hobson, The state and International Relations (Cambridge: Cambridge University Press, 2000), 223-228.

37 Schlumberger, "Dancing with Wolves," 39.

38 Daniel Ritter, The Iron Cage of Liberalism International Politics and Unarmed Revolutions in the Middle East and North Africa (Oxford: Oxford University Press, 2015), 207.

39 Anderson, "The State in the Middle East," 12-13.

40 Saouli, "Back to the future," 320-321.

${ }^{41}$ Hinnebusch, "Towards a Historical Sociology of the Arab Uprising," 44. 
the institutional approaches, Schlumberger draws attention to neopatrimonial ties. ${ }^{42}$ Therefore, within a historical perspective to the state formation process, the relation between state and social groups (civil society, political and economic interest groups, and identities) should be considered without underestimating the underlying dynamics. The historical sociology perspective, in this respect, requires complementation via integrating the structure and agency, as Hobden underlines a multilevel of causality. ${ }^{43}$ Sorensen points on the infeasibility of democratization laws and futile efforts to draw an absolute relationship between certain preconditions and democratization-democracy, which is undoubtedly ruling out the agential power in the processes ${ }^{44}$ Hinnebusch acknowledges that historical sociology does not provide an analysis of agential dynamics. ${ }^{45}$ To overcome the lack of agency, ideas, and discourse in the historical sociology approach, the integration of the political economy of regime security can be complementary.

\section{What Happened Politically in Modern Libya?}

The political processes that brought in the revolts must be searched in the articulation of state institutions in Libya. The policies of the Libyan regime had been decisive. ${ }^{46}$ The political-economic basis of Libya has been transformed under the impact of globalization/neoliberalization, and crony capitalism has become one of the main features of the statesociety complex. ${ }^{47}$ Such a transformation undermined the legitimacy of the regime, which is conceptualized as the "democracy of bread" by Sadiki. It means that demands for democracy are traded for the material interests

42 Schlumberger, "The Arab Middle East," 115.

43 Stephen Hobden, "Historical Sociology: back to the future of international relations," in Historical Sociology of International Relations, ed. Stephen. Hobden and John M. Hobson (New York: Cambridge University Press, 2002), 43.

44 Georg Sorensen, Democracy and Democratization: Processes and Prospects in a Changing World (3rd ed, Boulder Colorado: Westview Press, 2007), 32-33.

45 Hinnebusch, "Historical Sociology," 140.

46 Frederic Volpi, "Explaining (and re-explaining) political change in the Middle East during the Arab Spring: trajectories of democratization and of authoritarianism in the Maghreb," Democratization 20, no.6 (2013): 979.

47 Hinnebusch, "Towards a Historical Sociology of the Arab Uprising," 46. 
through distributive mechanisms. ${ }^{48}$ The course of events that culminated in the context for revolts, in this respect, becomes intimately related to the transformation of political-economic structures. The processes of political transformation entail the examination of Qadhafi's revolution in September 1, 1969 and the pre-revolutionary structures.

The context of Libyan independence incorporates colonial powers and socio-political resistance. After the Italian withdrawal in the post-WWII era, British and French influence started to be felt, ${ }^{49}$ and thanks to the Sanussi movement, dominant in the social sphere, ${ }^{50}$ King Idris (1950) succeeded in recognition of the autonomy of Benghazi, with the cooperation of Britain in 1949. However, the legitimacy of the new regime met serious problems in centralizing the authority because of the federative structure, ${ }^{51}$ which directly resulted from the tribal nature of Libya and oppositional attitude adopted by most of the tribes. ${ }^{52}$ Among the other issues exacerbating the already weak legitimacy of the king was a non-participatory and nontransparent state-building process. Income distribution was not equal; corruption and bribery were prevalent, especially after the discovery of oil in $1959,{ }^{53}$ the share of people from increasing oil revenues did not rise as expected. ${ }^{54}$ Besides, the king adopted a pro-western attitude during the Cold War and formed a parallel military power along with the army. ${ }^{55}$

The ideational conditions which ushered in the rise of Qadhafi as a political leader and the military coup toppling the monarchy should be looked at the regional figure, the leader of Egypt Gamal Abdul Nasser and his promotion

48 Larbi Sadiki, "Popular Uprisings and Arab Democratization," International Journal of Middle East Studies 32, no.1 (2000): 79.

49 Ira M. Lapidus, A History of Islamic Societies (Cambridge: Cambridge University Press, 2002), 713; Dirk Vandewalle, A History of Modern Libya $\left(2^{\text {nd }}\right.$ ed, Cambridge: Cambridge University Press, 2012), 24-30.

50 Ahmet Kavas, "Senussiyye Tarikat1," in Türkiye Diyanet Vakfi İslam Ansiklopedisi 21, Vol. 36 (2000), 536-538.

51 Türkkaya Ataöv, Afrika Ulusal Kurtuluş Mücadeleleri (Ankara: Ankara Üniversitesi Siyasal Bilgiler Fakültesi Yayınları, 1975), 107.

52 Vandewalle, A History of Modern Libya, 61-69.

53 Daniel Yergin, Petrol (Türkiye İş Bankası Kültür Yayınları, 1999), 611-612.

54 Gustave E. Grunebaum, İslamiyet Vol. III (Ankara: Bilgi Yayınevi, 1993), 228.

55 Roger Owen, State, Power and Politics in the Making of Modern Middle East (London: Routledge, 2004), 54; Grunebaum, İslamiyet, 229. 
of Arab nationalism. The political resistance against colonial powers and the political rhetoric of independence contributed to the formation of the social base for the revolution in Libya. Then young Qadhafi started his political career as "primus inter pares" and his power was derived from a charismatic leadership. ${ }^{56}$ Colonel Qadhafi toppled the Sanussi monarchy rule with a military coup led by the Free Unionist Officers (FUO). Following the coup, the oil production was nationalized. It was a significant move in that it provided the revolutionary regime with the economic base necessary for the implementation of revolutionary policies, although it also culminated in Libya's becoming a pariah state.

Qadhafi envisioned a model of state and society when he declared Jamahiriya with a slogan "freedom, socialism and unity" and toppled the monarchy of Al-Sanussi. His model was a mixture of liberalism, Arab nationalism, and socialism. The religion, on the other hand, held an instrumental role in the ideological framework of Qadhafi. In the first years of revolution, the Islamist groups were not purged, yet transformed into a functional position for the socialist order in Qadhafi's model. ${ }^{57}$

In 1973, at Zuwara speech, Qadhafi declared the People's Revolution, as stated in the Green Book. Until the "Green Book," the ideological and revolutionary fervor did not emerge clearly. ${ }^{58}$ State structures were transformed in 1977; the "Proclamation of People's Power" was constitutionally solidified.

The articulation of state institutions in Libya can be conceived of forming around the distributive and security functions. Although the new system could be thought of as a form of direct democracy, two particular institutions emerged in these processes: People's Congresses (legislative purposes) and People's Committees (executive purposes). The basis of power, on the other hand, remained in the hands of Revolutionary Committees (for the protection of revolution), which had no basis in the constitution. It was a privileged security organ. It can be argued that through these processes,

\footnotetext{
56 Vandewalle, A History of Modern Libya, 77.

57 Azzedine Layachi, "Islam and Politics in North Africa," in The Oxford Handbook of Islam and Politics, ed. Juan L. Esposito and Emad El-Din Shahin (New York: Oxford University Press, 2013), 355-356.

58 Vandewalle, A History of Modern Libya, 94.
} 
the revolutionary Libyan state acquired two separate and competing political sectors: Revolutionary Sector, on the one hand, which was for the mobilization of masses and protection of the revolution. It was constituted with those who were close to Qadhafi, and laws did not regulate it. The Ruling Sector, on the other, was the core of Jamahiriya consisting of People's Congress and People's Committees, which were regulated by laws and promulgated by the General People's Congress. ${ }^{59}$

The executive and legislative organs had no constitutional basis in Jamahiriya as the slogans of the revolution- freedom, socialism, and unityhad no constitutional basis. ${ }^{60}$ Looking at Qadhafi's perspective, the statebuilding and institutions reflected his family-tribe-state ranking. For him, family comes before state, which is defined as artificial political, economic, and sometimes military system and undoubtedly political, economic, or military factors tying several families into one. ${ }^{61}$

The reconstruction of the revolutionary Libyan state and smashing state institutions created limited space for civil society and political participation. The "Green Book" actually referred to the consultation as a governance, not including representation and reducing the opposition to the regime itself. $^{62}$ It is essential to state that the processes of institutionalization in Qadhafi's model inherited essential features from the political regime of the Sanussi monarchy. While political pluralism was not allowed and the election for the revolutionary leadership was seen unnecessary, ${ }^{63}$ political structures in Libya turned into repressive and exclusionary ones.

It is indicated in the ideological framework of the Green Book that Qadhafi had an elusive conception of democracy. Although he concluded that it was genuine democracy in Libya, he also acknowledges that the strongest

59 Amal S. M. Obeidi, "Political Elites in Libya since 1969," in Libya since 1969: Kaddafi's Revolution Revisited, ed. Dirk Vandewalle (New York: Palgrave Macmillian, 2008), 109.

60 Hanspeter Mattes, "Formal and Informal Authority in Libya since 1969," in Libya since 1969: Kaddafi's Revolution Revisited, ed. Dirk Vandewalle (New York: Palgrave Macmillian, 2008), 55-56.

61 M. Al-Kaddafi, Green Book, 101-102.

62 Vandewalle, A History of Modern Libya, 102-103.

63 Mattes, "Formal and Informal," 57. 
always rules and the stronger party is the ruling in society ${ }^{64}$ What he had in mind, however, was closer to the subordination of masses to his regime. In this regard, Qadhafi emphasized the importance of loyalty and obedience for the state's survival:

The more the families of a tribe feud and become fanatical, the more the tribe is threatened. The family is threatened when its individual members feud and pursue only their personal interests. Similarly, if the tribes of a nation quarrel and pursue only their own interests, then the nation is undermined. ${ }^{65}$

The economic basis of the Libyan model, on the other hand, was thought as a socialist economic order in the second part of the Green Book. It not only criticized the existing economic orders but also attempted to provide an instrumentalist Islamic interpretation of socialism. Along with wage labor, this model touched upon the rights of workers, ownership, and income; the role of the traders was abolished. Private businesses were closed and the economic base of the ulama was aimed to be undermined. ${ }^{66}$ For Qadhafi, the only way to end the processes of domination and exploitation was to ensure that everyone gets their equal share from the production.

Furthermore, in the Green Book's second part, private property was aimed to be transferred to collective ownership:

The aspiration of the new socialist society is to create a society which is happy because it is free. This can only be achieved by satisfying man's material and spiritual needs, and that, in turn, comes about through the liberation of these needs from the control of the others. Everyone has the right to beneficially utilize it by working, farming or pasturing as long as he and his heirs live on it- to satisfy their needs, but without employing others with or without a wage. ${ }^{67}$

Income was conceived as both a kind and a source of exploitation; therefore, the termination of income was crucial in getting rid of all kinds of exploitation. Yet, acknowledging the difficulty of this process, Qadhafi emphasized the institutionalization of the socialist mode of production: "Society will become fully productive; the material needs of society will be

\footnotetext{
64 Obeidi, "Political Elites," 111.

65 Al-Kaddafi, Green Book, 109.

66 Ibid., 57-58.

67 Ibid., 70-71.
} 
met" ${ }^{18}$ and the need for currency would be ended. ${ }^{69}$ Indeed, this step was to do away with private trading. ${ }^{70}$ In the "Green Book", man's basic needs were defined as house, income, and a vehicle, the others such as renting a house and hiring vehicles can be seen as instruments of domination ${ }^{71}$ which were abolished thanks to the revolution. ${ }^{72}$ The banking system was ceased to be used as an intermediary institution, became a repository of surplus funds. ${ }^{73}$ However, the penetration of the regime into the economic sector did not stop at that point. In 1981, General People's Congress announced that it assumed import, export and distribution functions. Private enterprise was largely replaced with the centrally-commanded economy. ${ }^{74}$

The Revolutionary Council, being directly responsible to Qadhafi, started to dominate the political life along with the economic sector. They could judge and sentence whomever they wanted; they were very powerful. ${ }^{75}$

Regarding the security and enforcement, Free Unionist Officers played a vital role in the army and had great privileges to protect the regime, and the bureaucracy was mostly dependent on Qadhafi. Qadhafi's security considerations motivated the elections of the governors. ${ }^{76}$ The reforms after the revolution enabled the regime to widely penetrate various domains of society while undermining the formation of an autonomous economic base. The various segments in society became dependent on the regime without having an outlet to raise their political demands.

Still, Qadhafi did not underestimate the relationship between the social base of inequality and political opposition:

To view the minority as political and economic substrata is dictatorial and unjust. ${ }^{77}$ Contemporary national liberation movements will not come

68 Ibid., 84.

69 Ibid., 83-84.

70 Mattes, "Formal and Informal," 66.

71 Al-Kaddafi, Green Book, 68-69.

72 Ronald B. St. John, "The Libyan Economy in Transition Opportunities and Challenges," in Libya since 1969: Kaddafi's Revolution Revisited, ed. Dirk Vandewalle (New York: Palgrave Macmillan, 2008), 129.

73 Vandewalle, A History of Modern Libya, 105-107.

74 St. John, "The Libyan Economy," 130.

75 Mattes, "Formal and Informal," 67-68.

76 Ibid., 64-65.

77 Al-Kaddafi, Green Book, 146. 
to an end before every group is liberated from the domination of another group..$^{78}$

The oil revenues became quite essential in the containment and subordination of any reactionary responses from the society. The oilbooms in the 1970s notably contributed to the repressive capacities of the regime. Altunışı argues that the political and social structures in Libya were transformed profoundly through the distributive mechanisms of the state; however, these processes resulted in the consolidation of tribal, regional, and family affiliations. ${ }^{79}$ In Libya, political elites were formed according to the regime's needs; temporary elites were created. ${ }^{80}$ Any formation of the political-social group, the union must take permission from the Ministry of Interior. Those who did not conform to the September Revolution's principles were not licensed. Likewise, the institutional basis of the state reduced the influence of tribes. Qadhafi saw the tribes, parties, classes, sects as dictatorial instruments of power. However, tribes were not negated as a whole, only seen as blood relations and in a social way: ${ }^{81}$ "The tribe is a natural social umbrella for social security" ${ }^{82}$ In return for loyalty, tribes were provided with material incentives. Within the framework of the supreme authority of the Revolutionary Command Council (RCC), there was a selective alliance with tribes.$^{83}$ The regime was founded on a narrowbased constituency and hinged upon the loyalty of certain tribes along with security institutions. It was the populist and distributive policies that ensured political quiescence. ${ }^{84}$ The regime's grip to power and its politically structured institutions, organizations, and political groups were intimately related. Among the methods used, there were outright repression, physical liquidation and revitalization of tribal structure in society through political reforms. ${ }^{85}$

\section{Ibid., 92.}

79 Meliha B. Altunışık, "Rentier State Theory and the Arab Uprisings: An Appraisal," Uluslararası İlişkiler 11, no.42 (2014): 79.

80 Obeidi, "Political Elites," 105.

81 Mattes, "Formal and Informal," 71.

82 Al-Kaddafi, Green Book, 108.

83 Ronald B. St. John, "Libya's Authoritarian Tradition," in Modern Middle East Authoritarianism Roots, Ramifications, and Crisis, ed. Noureddine Jebnoun, M. Kia and M. Kirk (New York: Routledge, 2013), 127-131.

84 Vandewalle, A History of Modern Libya, 95.

85 Mattes, "Formal and Informal," 55. 
Although the revolutionary Libyan regime managed to consolidate its power upon society and directed the political processes without confronting any domestic opposition, the implications of the international/regional context upon the political processes in Libya started to become essential throughout the 1980s. The fluctuations in oil prices directly affected the performance of the etatist economic model, which demonstrates its weaknesses.

Furthermore, the sanctions regime imposed upon Libya because of its involvement in terrorist activities and Libya's international pariah status had severe ramifications for the society. Regionally, the military failure in Chad demonstrated the limits of Libya's capacities. All these developments contributed to accumulating domestic discontent and made it more difficult for the regime to contain opposition. The halts in distributive mechanisms and the increasing inequality were the main driving factors behind the discontent. ${ }^{86}$

The actions taken by the regime, in such a context, indicated the complexity of political processes. Although consolidated through distributive mechanisms and subordinated opposition, the regime could not manage total autonomy from society. Furthermore, the attempts of liberalization acquired a specific form in the face of the problems for the regime. There were three main challenges for the regime; first, new institutions for regulation and transparency; second, reforming the distributive function of the state, introduction of the market and competitive forces; third, containment of whatever the results of these reforms ${ }^{87}$ The reform policies, however, did not go beyond the economic sector.

There were two attempts of economic liberalization (infitah) one in 19871990 and after 1990; however, the attempts of liberalization did not create inclusionary and democratic political processes. These attempts aimed transparency, decline in state subsidies, and incorporation of private sector initiatives to the market in order to overcome adverse effects of the stagnant and inefficient command-style economy. The diversification of economic sectors and creating a competitive environment for Foreign Direct Investment were important to attract finance. ${ }^{88}$

\footnotetext{
86 Vandewalle, A History of Modern Libya, 144.

87 Ibid., 160.

88 St. John, “The Libyan Economy,” 127.
} 
Revolution within revolution signaled an attempt to create an economic liberalization letting private capital and labor becoming partners in collectives; the Import Substitution Industrialization strategy was reversed. Furthermore, in 1988, the Ministry of Mass Mobilization and Revolutionary Leadership were created to limit the role of the $\mathrm{RC} .{ }^{89}$ Concerning political and civil rights, the General People's Congress adopted the "Great Green Charter of Human Rights". Although it provided some social rights and freedoms, there was still lacking a sound framework for political and civil rights. In this context, the domestic opposition was tried to be contained by the selective curtailment of RC's functions. ${ }^{90} \mathrm{RC}$ 's functions were decreased, and the Ministry of Mass Mobilization was created for charging corruption. Great Green Charter was influential in the sense of reversing the arbitrariness of the revolutionary decade. For instance, private property was protected again, and the independence of the judiciary was ensured. However, it was made powerless because of the article that unless it harmed the public interest. ${ }^{91}$

The main reason behind these reforms was the containment of domestic discontent and satisfying the international finance capital, along with alleviating the harms of intensified international political isolation during the 1980s. ${ }^{92}$ The reforms in Libya only remained as cosmetic changes. An independent civil society was not allowed to flourish. In a sense, it was entrenched authoritarianism. The failed attempt to introduce market economy concerned many privileged in patronage and close with the regime ${ }^{93}$ which ended up with limiting the enthusiasm for reforms.

There were domestic as well as international factors behind the failure of these attempts. The main reason for the crisis was that the distributive state conflicted with the West. ${ }^{94}$ Altunışık argues that the first important factor was the inappropriate international environment, which limited the choices

\footnotetext{
Ibid., 131.

Vandewalle, A History of Modern Libya, 138-141.

Ibid., 142.

St. John, "The Libyan Economy," 131-132.

Ibid., 135.

94 Leila S. Talani, The Arab Spring in the Global Political Economy (New York: Palgrave Macmillan, 2014), 225.
} 
before the regime. ${ }^{95}$ Secondly, it was the increasing density of domestic criticisms because of the deteriorating economic conditions. The economic sector in the late 1990s was highly inefficient, highly corrupted; money was spent on keeping coalitions loyal, lucrative, and extravagant projects with no developmental return were pursued. It is dramatic in the sense that the reforms determined the state's role in the economy directly affecting the legitimacy of the regime, patronage relations, and its survival. In other words, the success of reforms required the institutions that were smashed during the revolution. Therefore, after the $1990 \mathrm{~s}$, the reforms aimed to take the burden off from public-institutions, to manage the decline in state employment, to have success in the decentralization of authority (from GPC to local), yet ended up with increases in the price of commodities, ${ }^{96}$ which revealed that the Green Book ideology could not be implemented any more without providing the oil for wheels.

Such an economic condition was the outlook when it came to the 2000s. The economy was still ailing; employment was still provided mostly by the public sector, and hydrocarbon revenues constituted a vast amount of Gross Domestic Product (GDP). The years between 2003 and 2011 demonstrated that the economic and political reforms should complement each other. However, the political-security concerns were still driving the economic reforms. After 2003, the conditions were more auspicious than the 1970s and $1980 \mathrm{~s}$, when there was will to reform. ${ }^{97}$ The main obstacle before realizing the reforms was the institutional capacity, smashed during the revolution, along with the lukewarm efforts of the regime fearing to lose its grip to power. ${ }^{98}$ Nevertheless, the 2000 s were significant in the sense that relations between the Libyan regime and the international community showed progress.

The relations started to change when Qadhafi gave up its support for terrorist movements. The Iraqi invasion in 2003 and the 9/11 Terrorists Attacks to the Twin Towers were significant international factors in this change. The possibility of cooperation against terrorism contributed to the rehabilitation of Libya's relations with the international system. ${ }^{99}$

95 Meliha B. Altunışık, "A Rentier State's Response to Oil Crisis: Economic Reform Policies in Libya," Arab Studies Quarterly 18, no.4 (1996): 55.

96 Vandewalle, A History of Modern Libya, 188.

97 Ibid., 189-190.

98 Altunışık, “A Rentier State's Response," 56.

99 Ritter, The Iron Cage of Liberalism, 193. 
Noueihed and Warren underline that rehabilitation in relations manifested itself in the economic sector. In 2007, the Libyan regime signed agreements on oil. ${ }^{100}$ The changing international conditions facilitated the actions taken by the regime. Vandewalle argues that the rehabilitation of the internationally isolated position of Libya along with the US's harsh stance, however, helped the regime consolidating its power on society and strengthened the regime's capacity and legitimacy to repress opposition. ${ }^{101}$

\subsection{The Dynamics of the Revolts in Libya}

The framework of the study underlines the historical articulation of state institutions in the context of domestic and regional/international dynamics as decisive in the course of revolts in Libya. A look at the state-society complex in Libya before the uprisings demonstrates that tribal and familial relations consolidated because of the repressive and exclusionary political processes. Qadhafi's family members managed even the opposition to the regime in the form of the loyal opposition. Qadhafi's son Saifal-Islam became the leading figure in the course of Libya's globalization and rehabilitation into the international system. ${ }^{102}$ According to Joffe, the role of Saif alIslam as loyal opposition contributed to the growing sense of regime's losing grip on power, ${ }^{103}$ while the Islamist opposition was contained. ${ }^{104}$ The only option for the Libyan opposition was to organize abroad, which in 2005 formed a loose coalition of opposition groups under the National Libyan Opposition. Although it tried to coalesce in a meeting in London, the result was the "Declaration of National Consensus," which called for a return to constitutional legitimacy, creation of a transitional government, prosecution of all who are guilty against humanity. Nevertheless, the regime reacted indifferently regarding political contestation, which demonstrates the concern of Qadhafi on control of direct democracy. ${ }^{105}$

100 Lin Noueihed and Alex Warren, The Battle for the Arab Spring: Revolution, Counterrevolution and the Making of a New Era (London: Yale University Press, 2012), 165.

101 Dirk Vandewalle, "Libya's Revolution in Perspective: 1969-2000," in Libya since 1969: Kaddafi's Revolution Revisited, ed. Dirk Vandewalle (New York: Palgrave Macmillian, 2008), 37; George Joffe, "The Arab Spring in North Africa: origins and prospects," The Journal of North African Studies 16, no.4 (2011): 513.

102 Sadiki, "Libya's Arab Spring," 300.

103 Joffe, "The Arab Spring in," 523.

104 St. John, "Libya's Authoritarian," 134.

105 Ibid., 133. 
While the repressive policies of the regime after the war against terror lost a social basis, the public support to the regime against foreign powers diminished in time and paved the way for uprisings in Libya. ${ }^{106}$ The reasons underlying the quick transformation of protests into the uprisings, however, were three-fold: first was the because of the position of the military against the uprisings. The fragmented response of the military in Libya can be conceptualized as they had high interests and high restraints for engaging militarily on the civilians. For there were two units in the military, the elite units which were well-armed, equipped, and paid, and they were close to Qadhafi, while the regular army units was not paid well and constituted by lower strata. Furthermore, the tribal nature of society reflected itself in the army positions. Lastly, rather than merit, the loyalty of the personnel was appraised. ${ }^{107}$ The military units were kept depoliticized by promotions and rotations and military procurement. Although military procurement was declined after the 1980 s, it continued to be an outlet for public sector employment, ${ }^{108}$ which resulted in lacking identity in the military. The reaction of military forces in Libya had a striking influence on the course of uprisings. Taylor argues that military regimes became the arbiter of social unrest in Libya. ${ }^{109}$ It would be illuminating to mention that Libyan society (especially tribes) and security forces demonstrated fragmented responses, directly resulted from the patrimonial relations between the regime and social groups.

The second factor was related to repressive policies of the regime and consolidated economic inequalities that had divisive implications in society. The articulation of state institutions could not manage the inclusion of politicized masses. In the beginning, the protests enchanted the economic problems in Libya; however, the influence of the political structure, which prevented contestation and participation, on protest's transformation into civil war could not be ignored. The social structure of Libya formed along tribal lines rather than bureaucratic-institutional ones

\footnotetext{
106 The fact that increasing prices of food and energy contributed to the intensity of uprisings should not be underestimated. Joffe, "The Arab Spring in," 509.

107 William C. Taylor, Military Responses to the Arab Uprisings and the Future of CivilMilitary Relations in the Middle East Analysis from Egypt, Tunisia, Libya, and Syria (New York: Palgrave Macmillian, 2014), 158

108 Vandewalle, A History of Modern Libya, 145.

109 Taylor, Military Responses to the Arab Uprisings, 23.
} 
accelerated this process. It should not be forgotten that state institutions smashed during the revolution and marginalized groups due to repressive political actions of the regime primarily constituted the uprising turning out to be anti-Qadhafi movement.

The international/regional position on the uprisings constitutes the third factor. The swift transformation of protests into violent clashing between regime and opposition forces demonstrated that ensuring the containment of social instability was beyond the capacity of the regime. The international position of the Libyan regime, which is in crisis with the West for a long time, contributed to the legitimacy of intervention. The intervention was decided upon humanitarian purposes and supported by the League of Arab States (LAS) as well. It is known that the respect for state borders and non-intervention are among the commonly accepted norms of LAS. However, the context (the strategic interaction along with sectarian identities and power relations), most of the time, determined the course of reactions. For instance, the Libya case was an excellent example of the internalization of Western values such as humanitarian intervention by LAS. ${ }^{110}$ The conditions, considering the motivation of regional and international powers, can be argued to be conducive to international intervention. Qadhafi's harsh stance against the protests and showing no mercy while repressing the uprisings were crucial for the authorization of Security Council Resolution 1973, passed on 17 March 2011, to use military force primarily to protect civilian lives. Even though both regional and international legitimacy were provided in a short time, ${ }^{111}$ it can be argued that it was US, British and French-led mission; ${ }^{112}$ nevertheless, along with the violent nature of uprising in Libya, Engelbrekt and Vagnsson ${ }^{113}$ argue that the economic and energy dimensions of the Libyan intervention should not be underestimated. ${ }^{114}$

110 Avraham Sela, "The Vicissitudes of the Arab States System: From its Emergence to the Arab Spring," India Quarterly 73, no. 2 (2017):164-165.

111 Kjell Engelbrekt and Charlotte Wagnsson, "Introduction," in The NATO Intervention in Libya Lessons learned from the campaign, ed. Kjell Engelbrekt and Marcus Mohlin (New York: Routledge, 2013), 6.

112 Noueihed and Warren, The Battle for the Arab Spring, 182.

113 Engelbrekt and Wagnsson, "Introduction," 3-5.

114 Libya has 2 percent of world output, fifth-largest in the world, of oil reserves and 0.7 percent of natural gas reserves which is mostly 85 percent, sold to the European markets. 


\section{Conclusion}

The study underlines the contributions of a historical sociology perspective to account for the political processes in Libya. It is asserted that imposing a pre-determined framework as in the democratization/robustness of authoritarianism could not capture the complexity of protests turning into a civil war.

Instead of transitory frameworks, the study elaborates on asking what happened politically in Libya in order to understand the political-economic basis of the Libyan state-society complex. The articulation of state institutions in a repressive and exclusionary manner had been decisive in the undermining of the Qadhafi regime. Hinnebusch draws attention to the political-economic nature of transition in Middle East countries, which created crony capitalism. ${ }^{115}$ The tribal and patrimonial relations contributed to the conflicts after the fall of the regime. The structural organization of the Libyan state has been crucial in the unfolding of civil war. ${ }^{116}$ The democracy of bread ensures the ruling bargain between statesociety, which gives legitimacy to the governance in Sadiki's words. It demonstrates that democracy demands in the sense of political participation are traded for material interests via the distributive function of the state. ${ }^{117}$ Schlumberger shows how the arbitrary implementation of the legal framework marginalizing excluded groups increased the inequality within the society, which can be argued to push the masses to the violent uprising as an only way to voice their demands. ${ }^{118}$

With regards to a healthy and legitimate formation of authority in Libya, the intervention was just a step in the process; after Qadhafi was killed by the rebel groups, the attempts to build governance in Libya reflected the legacies of the ancien regime again. The tribal nature of the Libyan society poses another obstacle after toppling the state authority. Moreover, whether the contestation between fragmented social groups in Libya

\footnotetext{
115 Hinnebusch, "Towards a Historical Sociology of the Arab Uprising," 46.

116 Joffe, "The Arab Spring in," 507.

117 Sadiki, "Popular Uprisings," 79.

118 Oliver Schlumberger, "Structural Reform, Economic Order, and Development: Patrimonial Capitalism," Review of International Political Economy 15, no.4 (2008): 634
} 
results in a comprehensive political formation will be seen in time if the problems such as struggle over sharing oil revenues and the para-military formations filled up the power vacuum after the civil war could be solved fairly. In the face of the conflictual international/regional backdrop, the domestic issues pose certain obstacles before the political movements in Libya. It has a heterogeneous society; the tribal nature of Libyan society largely determines the course of events in Libya ${ }^{119}$ and the tribes, which can be argued to be non-political and non-ideological, and civil society organizations can help build the state. ${ }^{120}$

\section{Bibliography}

Altunış1k, Meliha B. "A Rentier State's Response to Oil Crisis: Economic Reform Policies in Libya." Arab Studies Quarterly 18, no. 4 (1996): 49-63.

Altunış1k, Meliha B. "Rentier State Theory and the Arab Uprisings: An Appraisal.” Uluslararası Illişkiler 11, no. 42 (2014): 75-91.

Anderson, Lisa. "The State in the Middle East and North Africa." Comparative Politics 20, no. 1 (1987): 1-18.

Anderson, Lisa. "Absolutism and the Resilience of Monarchy in the Middle East.” Political Science Quarterly 106, no. 1 (1991): 1-15.

Anderson, Lisa. "Searching Where the Light Shines: Studying Democratization in the Middle East." Annual Review of Political Science 9, (2006): 189-214.

Ataöv, Türkkaya. Afrika Ulusal Kurtuluş Mücadeleleri. Ankara: Ankara Üniversitesi Siyasal Bilgiler Fakültesi Yayınları, 1975.

Bellin, Eva. "Reconsidering the Robustness of Authoritarianism in the Middle East: Lessons from the Arab Spring." Comperative Politics 44, no. 2 (2012): 127-149.

Bhaskar, Roy. A Realist Theory of Science. New York: Routledge, 2008.

119 Taylor, Military Responses to the Arab Uprisings, 9.

120 Ibrahim Fraihat, Unfinished Revolutions: Yemen, Libya, and Tunisia after the Arab Spring (New Haven: Yale University Press, 2016), 211-212. 
Brynen, Rex, Korany, Bahgat and Paul Noble. "Introduction: Theoretical Perspectives on Arab Liberalization and Democratization." In Political Liberalization and Democratization in the Arab World. Vol.1: Theoretical Perspectives, edited by Rex Brynen, Bahgat, Korany and Paul Noble, 3-27. Boulder, CO: Lynne Rienner, 1995.

Burnell, Peter. "Arrivals and Departures: A Preliminary Classification of Democratic Failures and Their Explanation." Commonwealth \& Comparative Politics 36, no. 3 (1998): 1-29.

Carothers, Thomas. "The End of the Transition Paradigm." Journal of Democracy 13, no.1 (2002): 5-21.

Cavatorta, Francesco. "The Middle East and North Africa." In Routledge Handbook of Democratization, edited by Jeffrey Haynes, 79-93. New York: Routledge, 2011.

Engelbrekt, Kjell and Charlotte Vagnsson. "Introduction." In The NATO Intervention in Libya Lessons learned from the campaign, edited by Kjell Engelbrekt, Marcus Mohlin and Charlotte Vagnsson, 1-13. New York: Routledge, 2013.

Ehteshami, Anoushiravan, Raymond Hinnebusch, Heidi Huuhtanen, Paola Raunio, Maaike Warnaar and Tina Zintl. "Authoritarian Resilience and International Linkages in Iran and Syria." In Middle East Authoritarianisms: Governance, Contestation and Regime Resilience in Syria and Iran, edited by Steven Heydemann and Reinoud Leenders, 222-242. Stanford, California: Stanford University Press, 2012.

Esposito, Juan. L. and James P. Piscatori. "Democratization and Islam." Middle East Journal 45, no. 3 (1991): 427-440.

Fraihat, Ibrahim. Unfinished Revolutions: Yemen, Libya, and Tunisia after the Arab Spring. New Haven: Yale University Press, 2016.

Hinnebusch, Raymond. "Authoritarian Persistence, Democratization Theory, and the Middle East: An Overview and Critique." Democratization 13, no.3 (2006): 373-395.

Hinnebusch, Raymond. "Historical Sociology and the Arab Uprising." Mediterranean Politics 19, no. 1 (2014a): 137-140.

Hinnebusch, Raymond. "Towards a Historical Sociology of the Arab Uprising: Beyond Democratization and Post-Democratization." In Routledge Handbook of the Arab Spring Rethinking Democratization, edited by Larbi Sadiki, 39-50. New York: Routledge, 2014b. 
Hobden, Stephen. "Historical Sociology: Back to The Future of International Relations." In Historical Sociology of International Relations, edited by Stephen Hobden and John M. Hobson, 42-59. New York: Cambridge University Press, 2002.

Hobson, John M. The State and International Relations. Cambridge: Cambridge University Press, 2000.

Hobson, John M. "What's at stake in "Bringing Historical Sociology back into International Relations?" Transcending "chronofetishism" and "tempocentrism" in International Relations. In Historical Sociology of International Relations, edited by Stephen Hobden and John M. Hobson, 3-41. New York: Cambridge University Press, 2002.

Joffe, George. "The Arab Spring in North Africa: Origins and Prospects." The Journal of North African Studies 16, no. 4 (2011): 507-532.

Kaddafi, Muammar. Green Book. No date, No Publisher.

Kavas, Ahmet. Senussiyye Tarikatı, Türkiye Diyanet Vakfi İslam Ansiklopedisi, 21, 2000.

Kurki, Milja and Colin Wight "International Relations and Social Science." In International Relations Theories: Discipline and Diversity, edited by Tim Dunne, Milja Kurki and Steve Smith, 14-35. Oxford: Oxford University Press, 2013.

Lapidus, Ira M. A History of Islamic Societies. Cambridge: Cambridge University Press, 1999.

Layachi, Azzedine. "Islam and Politics in North Africa." In The Oxford Handbook of Islam and Politics, edited by John L. Esposito and Emad El-Din Shahin. New York: Oxford University Press, 2013.

Mattes, Hanspeter. "Formal and Informal Authority in Libya since 1969." In Libya since 1969: Qadhafi's Revolution Revisited, edited by Dirk Vandewalle, 55-81. New York: Palgrave Macmillian, 2008.

McLean, Ian. "Democratization and Economic Liberalization: Which is the Chicken and Which is the Egg?." Democratization 1, no. 1 (1994): 27-40.

Noueihed, Lin and Alex Warren. The Battle for the Arab Spring: Revolution, Counter-revolution and the Making of a New Era. London: Yale University Press, 2012. 
Obeidi, Amal. S. M. "Political Elites in Libya since 1969". In Libya since 1969: Qadhafi's Revolution Revisited, edited by Dirk Vandewalle, 105126. New York: Palgrave Macmillian, 2008.

Owen, Roger. State, Power and Politics in the Making of Modern Middle East. London: Routledge, 2004.

Ritter, Daniel. P. The Iron Cage of Liberalism International Politics and Unarmed Revolutions in the Middle East and North Africa. Oxford: Oxford University Press, 2015.

Sadiki, Larbi. "Popular Uprisings and Arab Democratization." International Journal of Middle East Studies 32, no.1 (2000): 71-95.

Sadiki, Larbi. "Libya's Arab Spring: The Long Road from Revolution to Democracy." International Studies 49, no. 3\&4 (2012): 285-314.

Saouli, Adham. "Back to the future: the Arab uprisings and State (Re)formation in the Arab World." Democratization 22, no. 2 (2015): 315-334.

Schlumberger, Oliver. "The Arab Middle East and the Question of Democratization: Some Critical Remarks." Democratization 7, no. 4 (2000): 104-132.

Schlumberger, Oliver. "Dancing with Wolves: Dilemmas of Democracy Promotion in Authoritarian Contexts." In Democratization and Development, edited by Dietrich Jung, 33-60. New York: Palgrave Macmillian, 2006.

Schlumberger, Oliver. "Structural Reform, Economic Order, and Development: Patrimonial Capitalism." Review of International Political Economy 15, no.4 (2008): 622-649.

Sela, Avraham. "The Vicissitudes of the Arab States System: From its Emergence to the Arab Spring." India Quarterly 73, no. 2 (2017): $145-179$.

Sorensen, Georg. Democracy and Democratization: Processes and Prospects in a Changing World. Third Edition. Boulder, Colorado: Westview Press, 2007.

St. John, Ronald. B. "The Libyan Economy in Transition Opportunities and Challenges." In Libya since 1969: Qadhafi's Revolution Revisited, edited by Dirk Vandewalle, 127-151. New York: Palgrave Macmillian, 2008. 
St. John, Ronald. B. "Libya's Authoritarian Tradition.” In Modern Middle East Authoritarianism Roots, Ramifications, and Crisis, edited by Noureddine Jebnoun Kia, M. and Kirk, M. 123-141. New York: Routledge, 2013.

Stepan, Alfred and Juan J. Linz. "Democratization Theory and the "Arab Spring'." Journal of Democracy 24, no. 2 (2013): 15-30.

Talani, Leila. S. The Arab Spring in the Global Political Economy. New York: Palgrave Macmillan, 2014.

Taylor, William. C. Military Responses to the Arab Uprisings and the Future of Civil-Military Relations in the Middle East Analysis from Egypt, Tunisia, Libya, and Syria. New York: Palgrave Macmillian, 2014.

Tilly, Charles. Democracy. New York: Cambridge University Press, 2007.

Valbjorn, Morten. "Upgrading Post-democratization Studies: Examining a Re-politicized Arab World in a Transition to Somewhere." Middle East Critique 21, no. 1 (2012): 25-35.

Valbjorn, Morten. "Three Ways of Revisiting the (post-) Democratization Debate After the Arab Uprisings." Mediterranean Politics 19, no. 1 (2014): 157-160.

Valbjorn, Morten and Andre Bank. "Examining the 'Post' in PostDemocratization: The Future of Middle Eastern Political Rule through Lenses of the Past." Middle East Critique 19, no. 3 (2010): 183-200.

Vandewalle, Dirk. (2008). "Libya's Revolution in Perspective: 19692000." In Libya since 1969: Qadhafi's Revolution Revisited, edited by Dirk Vandewalle, 9-53. New York: Palgrave Macmillian, 2008.

Vandewalle, Dirk. A History of Modern Libya. Cambridge: Cambridge University Press, 2012.

Volpi, Frederic. "Explaining (and re-explaining) political change in the Middle East during the Arab Spring: trajectories of democratization and of authoritarianism in the Maghreb." Democratization 20, no. 6 (2013): 969-990.

Von Grunebaum, G. E. İslamiyet, vol. III. Ankara: Bilgi Yayınevi, 1993.

Wight, Colin. Agents, Structures and International Relations: Politics as Ontology. Cambridge: Cambridge University Press, 2006.

Yergin, Daniel. Petrol. Türkiye İş Bankası Kültür Yayınları, 1999. 